\title{
AMPLIFICATION OF $c$-MYC AND $M L L$ GENES AS A MARKER OF CLONAL CELL PROGRESSION IN PATIENTS WITH MYELOID MALIGNANCY AND TRISOMY OF CHROMOSOMES 8 OR 11
}

\author{
Angelova $\mathrm{S}^{1, *}$, Jordanova $\mathrm{M}^{2}$, Spassov $\mathrm{B}^{1}$, Shivarov $\mathrm{V}^{1}$, Simeonova $\mathrm{M}^{3}$, \\ Christov $\mathrm{I}^{4}$, Angelova $\mathrm{P}^{3}$, Alexandrova $\mathrm{K}^{5}$, Stoimenov $\mathrm{A}^{1}$, Nikolova $\mathrm{V}^{1}$, \\ Dimova $\mathrm{I}^{6}$, Ganeva $\mathrm{P}^{1}$, Tzvetkov $\mathrm{N}^{4}$, Hadjiev $\mathrm{E}^{5}$, Toshkov $\mathrm{S}^{1}$
}

*Corresponding Author: Svetlana Angelova, Laboratory of Cytogenetics and Molecular Biology, National Specialized Hospital for Active Therapy of Hematological Diseases, 6, «Plovdivsko pole», Sofia, 1756, Bulgaria; Tel.: +35929701133; Fax : +35929701107; E-mail: sv_angelru@abv.bg

\section{ABSTRACT}

Gene amplification (amp) is one of the basic mechanisms connected with overexpression of oncogenes. The $c-M Y C$ (located in 8q24) and MLL (located in 11q23) are the most often over represented genes that lead to a rapid proliferation of the affected cell clone in patients with myeloid neoplasms. Assessment of the level of amp c-MYC or amp MLL in the cases with trisomy $8(+8)$ or trisomy $11(+11)$ and myeloid malignances is necessary for a more precise estimation of the disease progression.

A total of 26 patients with acute myeloid leukemia (AML) and myelodysplastic syndromes (MDS) were included in the study: 18 with +8 , six with +11 and two with complex karyotypes suspected of the partial trisomy. Routine cytogenetic analysis and fluorescent

Laboratory of Cytogenetics and Molecular Biology, National Specialized Hospital for Active Therapy of Hematological Diseases, Sofia, Bulgaria

Children Hospital of Hematological Diseases, Sofia, Bulgaria

Department of Medical Genetics, Medical University Hospital, Pleven, Bulgaria

4 Department of Hematology, Medical University Hospital, Pleven, Bulgaria

5 Department of Hematology, Medical University Hospital, Sofia, Bulgaria

6 Department of Medical Genetics, Medical University, Sofia, Bulgaria in situ hybridization (FISH) were applied to indicate the chromosome alterations and genes amp in the bone marrow cells.

Amp c-MYC was observed in 12 from 18 (66.7\%) patients with +8 . All the patients with +11 demonstrated a different level of amp MLL. In most of the cases with MDS $(9 / 10)$, the coincidence of the +8 or +11 with amp c-MYC or amp $M L L$, respectively, leads to transformation to AML and/or short overall survival. Our data suggest that amp c-MYC and amp MLL develop in conformity with +8 and +11 , especially in cases with progressive deviations in the karyotype as an aggressive expansion of an aberrant cell clone and appearance of additional chromosome anomalies.

Key words: Gene amplification ( $(\mathrm{mp} p), c-M Y C$, $M L L$ genes, Acute myeloid leukemia (AML), Myelodysplastic syndromes (MDS), Myeloid malignancies, Trisomy chromosomes of 8 or 11

\section{INTRODUCTION}

The development of cancer is a step-wise accumulation of genetic and epigenetic alterations including chromosome rearrangements that, in most cases, involve proto-oncogenes. Production of multiple copies of particular gene or gene amplification ( $a m p$ ) is one of the basic mechanisms that lead to over expression of oncogenes [1]. It is a frequent event in solid tumors but is rather rare in malignant hemopathies $[1,2]$. 
Genes with affinity to genomic over representation in myeloid malignancy such as acute myeloid leukemia (AML) and myelodysplastic syndromes (MDS) and others, are $c-M Y C, M L L$ and more rarely RUNXI and ETV6 [3-7].

The $M L L$ gene (located in region 11q23) is a transcriptional factor that normally regulates expression of mir-196b, a hematopoietic microRNA located within the HoxA cluster [8]. The $M L L$ over expression resulting from amp of $M L L$ (amp $M L L$ ) leads to over expression of the functionally related HOX genes, provoking an increased cell proliferative capacity and survival, as well as a partial block in differentiation $[4,8]$. The presence of additional $M L L$ copies in the genotype of the patients with MDS increases the transformation potential of the affected cell clones, which results in evolution to AML [4].

The MYC proteins play a well defined role as the components of signal transduction pathways promoting both cell proliferation and apoptosis $[9,10]$. The $c-M Y C$ gene (located in region $8 \mathrm{q} 24$ ) is frequently over expressed in human cancers, but the downstream events contributing to the tumor genesis remain incompletely understudied $[3,10]$. The next step of the disease progression would be if the amp of $c-M Y C$ (amp c-MYC) and amp MLL is accompanied by proven over expressions of corresponding genes $[4,10]$.

Total or partial trisomy is an unbalanced karyotypic anomaly which is more frequently a secondary event in the development of a neoplasia [11]. Trisomy $8(+8)$ occurs in 10 to $20 \%$ of the cases with myeloid malignances in contrast to the more rare but non random aberration, trisomy $11(+11)$ [12-14]. According to the United Kingdom Medical Research Council (MRC) criteria and World Health Organization classification-based prognostic scoring system, the prognostic value of these anomalies for achieving a complete remission in AML and for transformation in MDS is intermediate, but if +8 or +11 is attendant with over representation or/and amplification of $c-M Y C$ and $M L L$ genes, the prognosis assessment would be worse $[4,10,15-16]$. The final step in the malignant cell clone development that predicts resistance to therapy is karyotype complexity [15]. The 8q24 (c-MYC) and $11 \mathrm{q} 23(M L L)$ gains were observed in about $40 \%$ of the cases with AML and complex karyotype [17]. The objective of this study was to investigate the correlation between cytogenetically defined +8 or +11 in karyotypes at a different level of clonal cell development with molecular genetically proved amp c-MYC or amp $M L L$ genes.

\section{PATIENTS AND METHODS}

Patient Group. A total of 26 patients aged 16 to 82 years (median about 62 years) were included in this study. The distribution at diagnosis was: 16 patients with overt AML, seven with secondary AML after MDS (sAML) and three with different types of MDS. Eighteen patients had +8 ; in half of them the tri- or tetrasomy 8 was a sole cytogenetic abnormality. There were additional karyotipical aberrations in the other nine cases. It was the only anomaly in three of the six cases with +11 ; the karyotypes in the other three cases were more complicated. Also included were two additional cases with complex karyotypes suspected for amp MLL. All patients with AML below or equal to 65 $(\leq 65)$ years of age were treated with induction therapy consisting of antharacycline (Idarubicine, Farmorubicine or Mitoxantrone) and cytarabine according to the standard protocols. Patients above $65(>65)$ years of age received chemotherapy with Cytosar only. Patients with MDS before transformation to AML received supportive therapy and after transformation were treated with standard chemotherapy. The study was approved by the local Ethics Committee of the National Hospital for Hematological Diseases. All participants had given written informed consent.

Cytogenetic Analysis. Routine cytogenetic analysis was performed on metaphase chromosomes from bone marrow samples using a direct method and after short-term 24- or 48 hour-culturing [18]. A minimum of 15 bone marrow metaphase cells were analyzed in each patient using GTG differentially-stained chromosomes at a discriminatory level of 300-400 bands per haploid count. Karyotypic findings were interpreted and described according to the International System for Human Cytogenetic Nomenclature (ISCN, 2009) [19].

Fluorescent In Situ Hybridization (FISH). Fluorescent in situ hybridization was performed according to the standard manufacturer's protocol (Vysis ${ }^{\circledR}$; Abbot Molecular Inc., Abbott Park, IL, USA) on interphase nuclei in suspension after a routine cytogenetic procedure and stored at $-20^{\circ} \mathrm{C}$. Locus-specific dual color $M L L$ break apart rearrangement probe and $c$ $M Y C$ break apart rearrangement probe (Vysis ${ }^{\circledR}$; Abbot Molecular Inc.) were used, and no less than 200 interphase nuclei per probe were analyzed. In these probes, 
the 5' portion of the $M L L$ gene (or $c-M Y C$ ) was labeled in green, and the 3' portion in red. Thus, the presence of two normal gene signals in the cell was visualized as dual composite signals (red + green). The gene deletion was detected as a single composite signal, and +8 (or +11 ) as three composite signals. The presence of more than three composite signals was considered as a $M L L$ (or $c-M Y C$ ) gene amp. We recognized amplification level as a significant if amp were observed in more than $10 \%$ of interphase nuclei, under the $10 \%$, as a low level amp.

\section{RESULTS}

Solely Tri- or Tetrasomy 8. In nine of 18 patients with an additional chromosome 8 , this aberration was an isolated clonal anomaly in the karyotype: seven patients with +8 and two patients with tetrasomy 8 . The FISH analysis does not show significant amp c-MYC in cases 1 through 7 (Table 1). In the karyotype of patients 1 to 4 , the +8 aberration occurred in a minor cell clone (from 10 to $33 \%$ of the analyzed metaphases). Correlation between the number of $c-M Y C$ fluorescent signals in the interphase nuclei and the cytogenetically detected +8 metaphases in the first four patients showed absence or no significant proliferative advantage of the aberrant cell clone. In cases 5 to 7 , the cell clone with the +8 anomaly had a proliferative advantage. Only two of our patients with solely +8 and without $a m p$ $c-M Y C$ have achieved a hematological remission. The other two patients from this group did not receive optimal dose chemotherapy due to complications during the neutropenic phase.

In patients 8 to 10 , a karyotype progression from tri- to tetrasomy 8 or from partial clonality to total expansion of the aberrant cell clone was observed. Tetrasomy 8 in these cases was accompanied by amp $c$ $M Y C$. In two patients with MDS and expansion of the cell clone harboring +8 and amp $c-M Y C$, the disease evolved to AML.

Trisomy 8 in the Karyotype With Additional Aberrations. Seven of eight patients (11 through 17) with +8 and additional chromosome aberrations, had a different level of amp c-MYC: two with low (under $10 \%$ ) and five with more than $10 \%$. Coincidence of composite chromosome anomalies and amp c-MYC in most of the cases correlate with transformation of MDS to AML and short survival (about 3 months) without achieving a hematological remission. Only one of the patients (17) with MDS-RARS (refractory anemia with ring sideroblasts) and low level of amp $c-M Y C$, had comparatively long (13 months) overall survival (OS) despite of his advanced age.

In conclusion, a different level of amp c-MYC was observed in 12 of $18(66.7 \%)$ patients with +8 . The karyotypes of patients with a significant level of amp $c-M Y C$ demonstrated progressive chromosome complications.

Trisomy 11 and Suspicion of Amp MLL Complex Karyotype. In two of the six cases with total or partial +11 expansion of the affected cell clone was observed. In four cases, a significant amp $M L L$ was recorded. Two patients with +11 (5 and 6) did not have a significant amp MLL (Table 2). The median OS in the patient group with the low level of amp MLL was longer than that of the other patients with +11 ( 6 vs. 2 months. respectively).

In the two cases with suspected amp $M L L$ and complex karyotype and rearrangements on chromosome 11 , there were low, $6 \%$ and significant, $67 \%$, levels of the amp MLL. Both had very short OS due to early death in induction. All patients with amp MLL and/or +11 did not achieve remission and had short survival times.

In conclusion, all our patients with +11 demonstrated a different level of amp MLL. The significant level of amp MLL in this group is correlated with a very short OS.

\section{DISCUSSION}

The biological mechanism of the oncoproliferative activity of the +8 cell clones is explained mostly with the gene dosage effect [20]. Some authors using microarray techniques observed overexpression of genes located on chromosome 8 in trisomic cells $[20,21]$. Further microarray analysis demonstrated that +8 MDS was notable for over expression of immune and inflammatory genes; some of these gene products also have roles in cellular proliferation and differentiation in an angiogenesis, whereas apoptotic inhibitors were down-regulated [22]. Another proposed explanation of the biological significance of the extra chromosome 8 was based on the observation of increased copies of the $c-M Y C$ gene that plays a central role as a downstream mediator of the myeloid leukemogenesis [23]. Furthermore, a comparative genomic hybridization ratio measurement revealed that a gain of $8 \mathrm{q} 24$ is 
Table 1. Cytogenetic and molecular genetic findings, achievement of complete remission and overall survival in patients with acute myeloid leukemia or myelodyplastic syndromes and trisomy 8.

\begin{tabular}{|c|c|c|c|c|c|c|}
\hline \# & $\begin{array}{l}\text { Sex- } \\
\text { Age }\end{array}$ & $\begin{array}{c}\mathrm{D}_{\mathrm{X}} \\
(\mathrm{FAB})\end{array}$ & Karyotype & $\begin{array}{l}\text { FISH Results } \\
\text { (c-MYC oncogene) }\end{array}$ & $\begin{array}{c}\text { CRD } \\
\text { (months) }\end{array}$ & $\begin{array}{c}\text { OS } \\
\text { (months) }\end{array}$ \\
\hline 1 & F-62 & AML-M4 & $47, \mathrm{XX},+8[2](10 \%) / 46, \mathrm{XX}[18](90 \%)$ & $2 \mathrm{Cs}-86 \% ; 3 \mathrm{Cs}-14 \%$ & no & $1^{\mathrm{a}}$ \\
\hline 2 & F-74 & AML-M0 & $47, \mathrm{XX},+8[4](27 \%) / 46, \mathrm{XX}[11](73 \%)$ & $2 \mathrm{Cs}-22 \% ; 3 \mathrm{Cs}-78 \%$ & no & 6 \\
\hline 3 & M-62 & AML-M4 & $47, \mathrm{XY},+8[3](15 \%) / 46, \mathrm{XY}[17](85 \%)$ & 2 Cs- $-91 \% ; 3$ Cs $-9 \%$ & 9 & $>11$ \\
\hline 4 & M-73 & AML-M0 & $47, X Y,+8[5](33 \%) / 46, X Y[10](67 \%)$ & 2 Cs- $-91 \% ; 3$ Cs- $-9 \%$ & no & 4 \\
\hline 5 & $\mathrm{~F}-26$ & AML-M5a & $47, \mathrm{XX},+8[12](60 \%) / 47, \mathrm{XX}$, add $(4)(\mathrm{p} 16),+8[8](40 \%)$ & 2 Cs $-8 \% ; 3$ Cs $-92 \%$ & 6 & 11 \\
\hline 6 & $\mathrm{~F}-28$ & AML-M4 & $47, \mathrm{XX},+8[19](95 \%) / 46, \mathrm{XX}[1](5 \%)$ & 2 Cs-39\%; 3 Cs- $-55 \% ; 4$ Cs-6\% & no & 3 \\
\hline 7 & M-65 & AML-M4 & $47, \mathrm{XY},+8[12](80 \%) / 46, \mathrm{XY}[3](20 \%)$ & 2 Cs- $-15 \% ; 3$ Cs $-77 \% ; 4$ Cs- $8 \%$ & no & 6 \\
\hline 8 & M-70 & AML-M4 & $47, \mathrm{XY},+8[10](50 \%) / 48, \mathrm{XY},+8,+8[6](30 \%) / 46, \mathrm{XY}[4](20 \%)$ & $\begin{array}{l}2 \text { Cs }-18 \% ; 3 \text { Cs }-42 \% \\
4 \text { Cs- } 32 \% ;>5 \text { Cs }-8 \%\end{array}$ & no & 6 \\
\hline 9 & F-16 & $\begin{array}{l}\text { MDS-RAEB } \\
\text { trans AML }\end{array}$ & $\begin{array}{l}\mathrm{ND} \\
48, \mathrm{XX},+8,+8[20](100 \%)\end{array}$ & $\begin{array}{l}2 \mathrm{Cs}-30 \% ; 3 \mathrm{Cs}-27 \% \\
4 \mathrm{Cs}-42 \% ;>5 \mathrm{Cs}-1 \% \\
2 \mathrm{Cs}-28 \% ; 3 \mathrm{Cs}-14 \% ; \\
4 \mathrm{Cs}-46 \% ;>5 \mathrm{Cs}-12 \%\end{array}$ & $\begin{array}{l}\text { no } \\
\text { no }\end{array}$ & $\begin{array}{c}15+9 \\
9\end{array}$ \\
\hline 10 & F-63 & $\begin{array}{l}\text { MDS-RAEB } \\
\text { trans AML }\end{array}$ & $\begin{array}{l}47, \mathrm{XX},+8[8](53 \%) / 46, \mathrm{XX}[7](47 \%) \\
47, \mathrm{XX},+8[15](100 \%)\end{array}$ & $\begin{array}{l}\text { ND } \\
2 \mathrm{Cs}-10 \% ; 3 \mathrm{Cs}-84 \% \text {; } \\
4 \mathrm{Cs}-3 \% ;>5 \mathrm{Cs}-3 \%\end{array}$ & no & $\begin{array}{c}10+3 \\
3\end{array}$ \\
\hline 11 & M-61 & AML-M0 & 47,XY,dup(1)(p13p32),del(7)(q11q32),+8 [17] (100\%) & $\begin{array}{l}2 \mathrm{Cs}-17 \% ; 3 \mathrm{Cs}-72 \% \\
4 \mathrm{Cs}-6 \% ;>5 \mathrm{Cs}-72 \%\end{array}$ & no & 3 \\
\hline 12 & M-82 & AML-M5b & $46, \mathrm{XY},-7,+8[5](28 \%) / 46, \mathrm{XY}[13](72 \%)$ & $\begin{array}{l}2 \mathrm{Cs}-32 \% ; 3 \mathrm{Cs}-48 \% \\
4 \mathrm{Cs}-13 \% ;>5 \mathrm{Cs}-7 \%\end{array}$ & $-{ }^{\mathrm{b}}$ & 2 \\
\hline 13 & M-68 & AML-M4 & $45-48, X,-Y,-5,-7,+8 \times 2,+9,+15,-16,+$ mar', + mar” $[15](100 \%)$ & $\begin{array}{l}2 \mathrm{Cs}-2 \% ; 3 \mathrm{Cs}-10 \% \\
3 \mathrm{Cs}-71 \% ;>5 \mathrm{Cs}-17 \%\end{array}$ & no & 2 \\
\hline 14 & M-62 & $\begin{array}{l}\text { MDS } \\
\text { trans AML }\end{array}$ & $47, \mathrm{XY},+8[13](87 \%) / 48, \mathrm{XY},+8,+19[2](13 \%)$ & $\begin{array}{l}2 \mathrm{Cs}-9 \% ; 3 \mathrm{Cs}-80 \% \\
4 \mathrm{C}-9 \% ;>5 \mathrm{Cs}-2 \%\end{array}$ & no & 4 \\
\hline 15 & M-61 & $\begin{array}{l}\text { MDS } \\
\text { trans AML }\end{array}$ & $\begin{array}{l}56-59, \mathrm{XY},+1,+2,+4 \times 2, \operatorname{del}(5)(\mathrm{q} 11 \mathrm{q} 31),+6-7,+8 \times 2, \operatorname{del}(11)(\mathrm{p} 13), \\
+15 \times 2,-19+20,+21,+\mathrm{r}(?),+\operatorname{mar}[15](100 \%)\end{array}$ & $\begin{array}{l}2 \text { Cs }-14 \% ; 3 \text { Cs }-54 \% \\
4 \text { Cs }-18 \% ;>5 \text { Cs }-14 \%\end{array}$ & no & 1 \\
\hline 16 & M-78 & $\begin{array}{l}\text { MDS } \\
\text { trans AML }\end{array}$ & $\begin{array}{l}\text { 46,XY,del(11)(q21q23),del(20)(q11-12) [2]/47,XY,+8,t(2;4) } \\
\text { (q23;q31),del(11)(q21q23),del(20)(q11-12) [8]/46,XY,t(9;22) } \\
\text { (q34;q11) [1]/47,XY,+8,t(9;22)(q34;q11) [4] (80\%) }\end{array}$ & $\begin{array}{l}2 \mathrm{Cs}-17 \% ; 3 \mathrm{Cs}-75 \% \\
4 \mathrm{Cs}-5 \% ;>5 \mathrm{Cs}-3 \%\end{array}$ & no & 4 \\
\hline 17 & M-81 & MDR-RARS & $\begin{array}{l}\text { 47,XY,+8 [18]/46,X,-Y,+8,dmin [2]/46,XY,del(7)(q21q31) [2]/ } \\
46, \mathrm{XY},[2](83 \%)\end{array}$ & $\begin{array}{l}2 \mathrm{Cs}-17 \% ; 3 \mathrm{Cs}-76 \% \\
4 \mathrm{Cs}-5 \% ;>\text { Cs }-2 \%\end{array}$ & $-^{\mathrm{b}}$ & 13 \\
\hline 18 & F-66 & $\begin{array}{l}\text { MDS } \\
\text { trans AML }\end{array}$ & $\begin{array}{l}\text { 45,XX,del(5)(q13),+8,-16,-18 [6]/45,idem,del(12)(q22q24) } \\
{[11] / 44, X X, \operatorname{del}(5)(\mathrm{q} 13),-7,+8, \operatorname{der}(11) \mathrm{t}(7 ; 11)(\mathrm{q} 11 ; \mathrm{p} 15),-16,-18} \\
{[8](100 \%)}\end{array}$ & 2 Cs $-88 \% ; 3$ Cs $-12 \%$ & no & 3 \\
\hline
\end{tabular}

$\mathrm{D}_{\mathrm{X}}$ (FAB): Diagnosis (French, American and British classification of hematological diseases); FISH: fluorescent in situ hybridization; CRD: complete remission duration; OS: overall survival; AML: acute myeloid leukemia; Cs: composite signal (red+green) detected on the intact $c-M Y C$ gene; MDS: myelodyplastic syndromes; RAEB: refractory anemia with excess of blasts; trans: transformation; RARS: refractory anemia with ring sideroblasts.

${ }^{\text {a }}$ Death due to heart attack before the second induction course.

${ }^{\mathrm{b}}$ Patient on supportive care only. 
Table 2. Cytogenetic and molecular genetic findings, achievement of complete remission and overall survival in patients with acute myeloid leukemia or myelodysplastic syndromes and trisomy 11.

\begin{tabular}{|c|c|c|c|c|c|c|}
\hline \# & $\begin{array}{l}\text { Sex- } \\
\text { Age }\end{array}$ & $\begin{array}{c}\mathrm{D}_{\mathrm{X}} \\
(\mathrm{FAB})\end{array}$ & Karyotype & $\begin{array}{l}\text { FISH Results } \\
\text { (MLL oncogene) }\end{array}$ & $\begin{array}{c}\text { CRD } \\
\text { (months) }\end{array}$ & $\begin{array}{c}\text { OS } \\
\text { (months) }\end{array}$ \\
\hline 1 & M-50 & AML-M5a & $47, \mathrm{XY},+11[20](100 \%)$ & $\begin{array}{l}2 \mathrm{Cs}-5 \% ; 3 \mathrm{Cs}-65 \% \\
4 \mathrm{Cs}-17 \% ;>5 \mathrm{Cs}-13 \%\end{array}$ & no & 2 \\
\hline 2 & M-74 & MDS-RAEB & 47,XY,+11 [11](55\%)/46,XY [9](45\%) & $\begin{array}{l}2 \mathrm{Cs}-46 \% ; 3 \mathrm{Cs}-31 \% \\
4 \mathrm{Cs}-11 \% ;>5 \mathrm{Cs}-12 \%\end{array}$ & no & 3 \\
\hline 3 & M-75 & AML-M4 & $48, \mathrm{XY},+11 \times 2[3](15 \%) / 46, \mathrm{XY}[17](85 \%)$ & $\begin{array}{l}2 \mathrm{Cs}-22 \% ; 3 \mathrm{Cs}-5 \% \\
4 \mathrm{Cs}-10 \% ;>5 \mathrm{Cs}-63 \%\end{array}$ & no & 1 \\
\hline 4 & M-64 & AML-M6 & $\begin{array}{l}\text { 45,XY,-3,-18,+R(?),del(5)q13q33),add(20)(p13) [2]/44,XY,-3, } \\
\text {-18,del(5)(q13q33),add(11)(q23),add(20)(p13) [6]/44,XY,-3, } \\
-18, \operatorname{del}(5)(\mathrm{q} 13 \mathrm{q} 33), \operatorname{ins}(11 ; ?)(\mathrm{q} 13 ; ?), \operatorname{add}(20)(\mathrm{p} 13[9] / 42, \mathrm{XY},-3, \\
-7,-18 \times 2, \operatorname{del}(5)(\mathrm{q} 13 \mathrm{q} 33), \operatorname{ins}(11 ; ?)(\mathrm{q} 13 ;>), \operatorname{add}(20)(\mathrm{p} 13)[9](92 \%)\end{array}$ & $\begin{array}{l}2 \text { Cs }-51 \% ; 3 \text { Cs }-29 \% \\
4 \text { Cs }-14 \% ;>5 \text { Cs- } 6 \%\end{array}$ & no & 1 \\
\hline 5 & M-72 & AML-M0 & $\begin{array}{l}\text { 46,XY,del(20)(q11) [2]/46,XY,ider(20)(p11.2),del(20)(q11q13) } \\
{[4] / 47, \text { idem,+11 [7]/46,idem,-Y,+11 [3] (62.5\%) }}\end{array}$ & 2 Cs- $13 \% ; 3$ Cs- $79 \% ; 4$ Cs- $8 \%$ & no & 6 \\
\hline 6 & M-47 & $\begin{array}{l}\text { MDS } \\
\text { trans AML }\end{array}$ & $\begin{array}{l}\text { 46,XY,del(12)(p11p12) [4]/46,XY,del(12)(p11p12), del(13) } \\
\text { (q13q22) [2]/46,XY,+11,-17,ins(1)(p13q21q32),der(9),t(9;17) } \\
\text { (q10;q10),del(13)(q13q22),del(16)(q22) [3]/46,XY [11] (15\%) }\end{array}$ & 2 Cs- $71 \% ; 3$ Cs- $21 \% ; 4$ Cs $-8 \%$ & no & 6 \\
\hline 7 & F-66 & AML-M0 & $\begin{array}{l}\text { 44,XX,-7,-11p+,-17,+18,+mar [7]/44-45,XX,-3,+6,-7,11p+,add } \\
(14)(\mathrm{q} 32),-16,+18,+22,+\operatorname{mar}[6](100 \%)\end{array}$ & $\begin{array}{l}2 \mathrm{Cs}-84 \% ; 3 \mathrm{Cs}-10 \% \\
4 \mathrm{Cs}-3 \% ;>5 \mathrm{Cs}-3 \%\end{array}$ & no & 2 \\
\hline 8 & M-69 & MDS-RAEB & $\begin{array}{l}\text { 56-80,XYY,-X,del(5)(q13),t(7;11)(q32;q12),del(13)(q13q32), } \\
+2 \mathrm{mar}[4] / 81-83, X Y Y,-X, \operatorname{del}(5)(\mathrm{q} 13), \mathrm{t}(7 ; 11)(\mathrm{q} 32 ; \mathrm{q} 12), \operatorname{del}(13) \\
(\mathrm{q} 13 \mathrm{q} 32), \mathrm{t}(14 ; 14)(\mathrm{q} 10 ; \mathrm{q} 10), \mathrm{t}(21 ; 21)(\mathrm{q} 10 ; \mathrm{q} 10),+2 \mathrm{mar}[9] \\
(100 \%)\end{array}$ & $\begin{array}{l}2 \text { Cs }-5 \% ; 3 \text { Cs }-28 \% \\
4 \text { Cs }-52 \% ;>5 \text { Cs }-15 \%\end{array}$ & no & 1 \\
\hline
\end{tabular}

$\mathrm{D}_{\mathrm{X}}$ (FAB): Diagnosis (French, American and British classification of hematological diseases); FISH: fluorescent in situ hybridization; CRD: complete remission duration; OS: overall survival; AML: acute myeloid leukemia; Cs: composite signal (red+green) detected on the intact $c-M Y C$ gene; MDS: myelodyplastic syndromes; RAEB: refractory anemia with excess of blasts; trans: transformation.

associated with mutation of the $p 53$ tumor suppressor gene. The association between the gain at an $8 \mathrm{q} 24$ and the $p 53$ mutation might be attributable to transactivation of the $c-M Y C$ gene by the $p 53$ promoter [24].

Amplification mechanisms are not yet clearly understood [1-2]. Chromosomes have hot fragile sites that break under specific conditions and may be associated with chromosomal instability in cancer as breakpoint sites for translocation, deletion, and amplification [9]. Low-level amp c-MYC was reported in a number of patients with +8 AML, +8 MDS and chronic myeloid leukemia (CML) in blast phase [25-27]. Some authors suggest that $c-M Y C$ is not the true target of the amp but that abundant expression of another gene(s) included in an 8q24 amplicon is the pathogenetically important consequence [28].

In most of our overt AML and sAML +8 cases, the visible developmental effects such as aberrant cell clone expansion and the occurrence of additional chromosome deviations are connected with amp c-MYC that was observed in 12 of 18 (66.7\%) patients. Ab- sence of an amp c-MYC was found predominantly in the cases with minor +8 cell clones. We suggest that amp c-MYC is a logical result of the development in the proliferating +8 cell populations.

The +11 is the third most common trisomy in de novo AML, which is more frequently associated with two different molecular genetic alterations: partial tandem duplication (PTD) and amp MLL gene [4,29-31]. In most of the cases, the amp 11q23 (with or without any microscopically visible alterations) is accompanied by $M L L$ gene over expression, which leads to a rapid proliferation of the affected clone and to disease progression $[4,31]$.

Our group of patients with +11 is quite small to make definitive conclusions. Most of our patients with +11 cell clone expansion also demonstrated an amp $M L L$. This could be explained by the rapid advance of the developmentally processes in the proliferating +11 cell clones. The significant level of amp MLL (>10\%) in cases which are suspected of gaining 11q23 in complex karyotype supported our developmental hypotheses. 
The prognostic value of +8 and +11 is contradictary. A number of authors defined them as an intermediate, others as an adverse prognostic factor [11$13,15]$. On the other hand, in most of the publications, the presence of amp c-MYC and amp MLL correlate with disease progression and poor risk for patients with myeloid malignancies $[10,14,21]$.

We speculate that the conflicting results can be explained with the difference in the proportion of patients who had amp c-MYC or amp MLL in different series. The absence of the gene amp can be logically connected with the early evolutionary stage of the disease and with the cohort of early diagnosed patients. If during the investigation, the later diagnosed patients with amp c-MYC or amp MLL predominate, a worse prognostic effect may be expected.

All of our AML patients with +8 and amp c-MYC had a short OS (about 3.7 months) without hematological remission as well as the patients with +11 and amp MLL (about 2.4 months). Two of our MDS patients with expansion of the tri- and tetrasomy 8 cell clones had amp c-MYC. Both of them demonstrated a resistance to chemotherapy, disease progression and transformation to AML. In contrast, two of the five patients with +8 without amp c-MYC, achieved hematological remission and one on them is still alive. We suppose that appearance of +8 and +11 in karyotype provoke the further developmental events such as $a m p$ $c-M Y C$ or amp MLL that leads to therapy resistance. The earlier patients with +8 and/or +11 are diagnosed, the higher are their chances not to have amp c-MYC or amp MLL and not to be resistant to treatment.

According to the results in our comparatively small patient group, we can assume that amp c-MYC and amp MLL are natural developmental events, especially in cases with an aggressive expansion of the aberrant cell clone and appearance of additional chromosome anomalies.

\section{REFERENCES}

1. Albertson D G. Gene amplification in cancer. Trends Genet. 2006; 22(8): 447-455.

2. Gajduskova P, Snijders AM, Kwek S, Roydasgupta R, Fridlyand J, Tokuyasu T, Pinkel D, Albertson DG. Genome position and gene amplification. Genome Biol. 2007; 8(6): R120.1-16.

3. Osthus RC, Karim B, Prescott JE, Smith BD, McDevitt M, Huso DL, Dang CV. The Myc target gene JPO1/ CDCA7 is frequently overexpressed in human tumors and has limited transforming activity in vivo. Cancer Res. 2005; 65(13): 5620-5627.

4. Poppe B, Vandesompele J, Schoch C, Lindvall C, Mrózek K, Bloomfield CD, Beverloo HB, Michaux L, Dastugue N, Herens C, Yigit N, De Paepe A, Hagemeijer A, Speleman F. Expression analyses identify $M L L$ as a prominent target of 11q23 amplification and support an etiologic role for $M L L$ gain of function in myeloid malignancies. Blood. 2004; 103(1): 229-235.

5. Andersen MK, Christiansen DH, Pedersen-Bjergaard J. Amplification or duplication of chromosome band 21q22 with multiple copies of the $A M L 1$ gene and mutation of the TP53 gene in therapy-related MDS and AML. Leukemia. 2005; 19(2): 197-200.

6. Mauvieux L, Helias C, Perrusson N, Lioure B, Sorel N, Brizard F, Lessard M. ETV6 (TEL) gene amplification in a myelodysplastic syndrome with excess of blasts. Leukemia. 2004; 18(8): 1436-1438.

7. Rayeroux KC, Campbell LJ. Gene amplification in myeloid leukemias elucidated by fluorescence in situ hybridization. Cancer Genet Cytogenet. 2009; 193(1): 44-53

8. Popovic R, Riesbeck LE, Velu CS, Chaubey A, Zhang J, Achille NJ, Erfurth FE, Eaton K, Lu J, Grimes HL, Chen J, Rowley JD, Zeleznik-Le NJ. Regulation of mir$196 \mathrm{~b}$ by MLL and its overexpression by MLL fusions contributes to immortalization. Blood. 2009; 113(14): 3314-3322.

9. Popescu NC, Zimonjic DB. Chromosome-mediated alterations of the $M Y C$ gene in human cancer. J Cell Mol Med. 2002; 6(2): 151-159.

10. Meyer N, Penn LZ. Reflecting on 25 years with $M Y C$. Nat Rev Cancer. 2008; 8(12): 976-990.

11. Farag SS, Archerd KJ, Mrozek K, Vardiman JW, Carroll AJ, Pettenati MJ, Morre JO, Kolitz JE, Mayer RJ, Stone $\mathrm{RM}$, Larson RA, Bloomfield CD. Isolated trisomy of chromosomes $8,11,13$ and 21 is an adverse prognostic factor in adults with de novo acute myeloid leukemia: Results from Cancer and Leukemia Group B 8461. Int J Oncol. 2002, 21(5): 1041-1051.

12. Grimwade D, Hills RK. Independent prognostic factors for AML outcome. Hematology Am Soc Hematol Educ Program. 2009; 385: 385-395.

13. Byrd JC, Mrozek K, Dodge RK, Carroll AJ, Edwards CG, Arthur DC, Pettenati MJ, Patil SR, Rao KW, Watson MS, Koduru PRK, Moore JO, Stone RM, Mayer RJ, Feldman EJ, Davey FR, Schiffer CA, Larson RA, Bloomfield CD. Pretreatment cytogenetic abnormalities are predictive of induction success, cumulative incidence of relapse, and overall survival in adult patients with de novo acute myeloid leukemia: results from Cancer and Leukemia Group B (CALGB 8461). Blood. 2002; 100(13): 4325-4336.

14. Wolman SR, Gundacker H, Appelbaum FR, Slovak ML. Impact of trisomy $8(+8)$ on clinical presentation, treatment response, and survival in acute myeloid 
leukemia: a Southwest Oncology Group study. Blood. 2002; 100(1): 29-35.

15. Mrozek K, Heerema NA, Bloomfield CD. Cytogenetics in acute leukemia. Blood Rev. 2004, 18(2): 115-136.

16. Malcovati L, Germing U, Kuendgen A, Della Porta MG, Pascutto C, Invernizzi R, Giagounidis A, Hildebrandt B, Bernasconi P, Knipp S, Strupp C, Lazzarino M, Aul C, Cazzola M. Time-dependent prognostic scoring system for predicting survival and leukemic evolution in myelodysplastic syndromes. J Clin Oncol. 2007; 25(23): 3505-3510.

17. Rucker FG, Bullinger L, Schwaenen C, Lipka DB, Wessendorf S, Fröhling S, Bentz M, Miller S, Scholl C, Schlenk RF, Radlwimmer B, Kestler HA, Pollack JR, Lichter P, Döhner K, Döhner H. Disclosure of candidate genes in acute myeloid leukemia with complex karyotypes using microarray-based molecular characterization. J Clin Oncol. 2006; 24(24): 3887-3894.

18. Schoch C, Schnittger S, Bursch S, Gerstner D, Hochhaus A, Berger U, Hehlmann R, Hiddemann W, Haferlach T. Comparison of chromosome banding analysis, interphase- and hypermetaphase-FISH, qualitative and quantitative PCR for diagnosis and for follow-up in chronic myeloid leukemia: a study on 350 cases. Leukemia. 2002; 16(1): 53-59.

19. International System for Human Cytogenetic Nomenclature (2009). Shaffer LG, Slovak ML, Campbell LJ, Eds. Basel: S. Karger, 2009.

20. Virtaneva K, Wright FA, Tanner SM, Yuan B, Lemon WJ, Caligiuri MA, Bloomfield CD, de La Chapelle A, Krahe R. Expression profiling reveals fundamental biological differences in acute myeloid leukemia with isolated trisomy 8 and normal cytogenetics. Proc Natl Acad Sci USA. 2001; 98(3): 1124-1129.

21. Schoch C, Kohlmann A, Dugas M, Kern W, Hiddemann W, Schnittger S, Haferlach T. Genomic gains and losses influence expression levels of genes located within the affected regions: a study on acute myeloid leukemias with trisomy 8,11 , or 13 , monosomy 7 , or deletion $5 \mathrm{q}$. Leukemia. 2005; 19(7): 1224-1228.

22. Chen G, Zeng W, Miyazato A, Billings E, Maciejewski JP, Kajigaya S, Sloand EM, Young NS. Distinctive gene expression profiles of CD34 cells from patients with myelodysplastic syndrome characterized by specific chromosomal abnormalities Blood. 2004; 104(13): 4210-4218.
23. Luo H, Li Q, O’Neal J, Kreisel F, Le Beau MM, Tomasson MH. c-Myc rapidly induces acute myeloid leukemia in mice without evidence of lymphoma-associated antiapoptotic mutations. Blood. 2005; 106(7): 2452-2461.

24. Jain AN, Chin K, Borresen-Dale A-L, Erikstein BK, Lonning PE, Kaaresen R, Gray JW. Quantitative analysis of chromosomal CGH in human breast tumors associates copy number abnormalities with p53 status and patient survival. Proc Natl Acad Sci USA. 2001; 98(14): 7952-7957.

25. Strout MP, Lorsbach RB, Shearer P, Sandlund JT, Raimondi SC. Double minute chromosomes and c-MYC amplification in a child with secondary myelodysplastic syndrome after treatment for acute lymphoblastic leukemia. Leukemia. 2000; 14(7): 1314-1315.

26. Jennings BA, Mills KI. C-MYC locus amplification and the acquisition of trisomy 8 in the evolution of chronic myeloid leukaemia. Leuk Res. 1998; 22(10): 899-903.

27. Slovak ML, Ho JP, Pettenati MJ, Khan A, Douer D, Lal S, Traweek ST. Localization of amplified MYC gene sequences of double minute chromosomes in acute myelogenous leukemia. Genes Chromosomes Cancer. 1994; 9(1): 62-67.

28. Storlazzi CT, Fioretos T, Paulsson K, Strömbeck B, Lassen C, Ahlgren T, Juliusson G, Mitelman F, Johansson RM. Identification of a commonly amplified 4.4 $\mathrm{Mb}$ region with overexpression of $\mathrm{C} 8 \mathrm{FW}$, but not $\mathrm{MYC}$ and MYC-containing double minutes in myeloid malignancies. Hum Mol Genet. 2004; 13(14): 1479-1485.

29. Whitman SP, Liu S, Vukosavljevic T, Rush LJ, Yu L, Liu C, Klisovic MI, Maharry K, Guimond M, Strout MP, Becknell B, Dorrance A, Klisovic RB, Plass C, Bloomfield CD. The MLL partial tandem duplication: evidence for recessice gain-of-function in acute myeloid leukemia identifies a novel patient subgroup for moleculartargeted therapy. Blood. 2005; 106(1); 345-352.

30. Tyybäkinoja A, Saarinen-Pihkala U, Elonen E, Knuutila S. Amplified, lost and fused genes in 11q23-25 amplicon in acute myeloid leukemia, an array-CGH study. Genes Chromosomes Cancer. 2006; 45(3): 258-264.

31. Michaux L, Wlodarska I, Stul M, Dierlamm J, Mugneret F, Herens C, Beverloo B, Verhest A, Verellen-Dumoulin C, Verhoef G, Selleslag D, Madoe V, Lecomte M, DeprijckB, Ferrant A, Delannoy A, Marichal S, Duhem C, Dicato M, Hagemeiher A. MLL Amplification in myeoloid leukemias: a study of 14 cases with multiple copies of 11q23. Genes Chromosomes Cancer. 2000; 29(1): 40-47. 
